\title{
ARE GOVERNANCE AND MANAGEMENT EFFECTIVE WITHIN PROTECTED AREAS OF THE KANCHENJUNGA LANDSCAPE (BHUTAN, INDIA AND NEPAL)?
}

\author{
Krishna Prasad Oli $^{1 *}$, Sunita Chaudhary ${ }^{1}$ and Uday Raj Sharma ${ }^{1}$ \\ *Corresponding author: koli@icimod.org \\ ${ }^{1}$ International Centre for Integrated Mountain Development (ICIMOD), GPO Box 3226, \\ Khumaltar, Kathmandu, Nepal
}

\begin{abstract}
An assessment was undertaken of the governance and related management effectiveness of four protected areas of the Kanchenjunga landscape shared by Bhutan, India and Nepal, using a simple site level tracking tool. The study was further supported by focus group discussion, a survey of key informants and site visits. The management assessment revealed that protected areas are consistently weak in inputs such as number of staff, equipment, financial provision and infrastructure. The results indicate that management improvements are needed. Khangchendzonga biosphere reserve and Singhalila National Park in India scored 41.98 per cent and 32.44 per cent respectively. Slightly higher, Kanchenjunga Conservation Area of Nepal and Toorsa Strict Nature Reserve of Bhutan scored 67.59 per cent and 58.02 per cent respectively. Weak institutional capacity, depredation by wildlife, livestock grazing and illegal harvesting of resources were identified as threats. Limited participation of local people in decision making and protected area management were seen as major challenges. The findings support the recommendation that efforts should be made to move from a protectionist approach to a community-based conservation approach for conservation and sustainable use of biological resources in the landscape.
\end{abstract}

KEYWORDS: management effectiveness, Kanchenjunga , Bhutan, India, Nepal, tracking tool, Singhalila, Toorsa, focus group discussion

\section{INTRODUCTION}

There are now some 160,000 protected areas listed on the World Database of Protected Areas, covering nearly 13 per cent of the world's terrestrial surface areas. Many of these are embedded in comprehensive national and regional networks of connected protected areas and corridors (Bertzky et al., 2012). This connectivity has been established by promoting, through participatory approaches, sustainable forest management and other conservation efforts along protected area boundaries (Bruner et al., 2001) and developing biological corridors to link habitats and ecosystems (Boyle et al., 2010). Despite these efforts it is not easy to answer the question of how effectively parks are being managed in the context of growing human pressure. Governance and management are as important to the planning and operation of protected areas as biodiversity conservation.

The Kanchenjunga Landscape (KL) which encompasses the southern stretch of landscape surrounding Mount Kangchenjunga $(8,586$ metres) spreads over diverse ecological zones in eastern Nepal, Darjeeling and Sikkim in India and western Bhutan (Figure 1 overleaf). Protected areas are established in the landscape for protection of globally threatened species, ecosystem restoration, recreation and to provide ecosystem services to the communities. They are managed in a variety of ways including by the government, co-managed, private management by local NGOs and community conserved areas (Kothari, 1999), under different rules and regulations. Spread over three countries, issues, challenges and governance vary based on each country's own context. However, these areas face similar conservation threats, many of which are transboundary in nature such as park-people conflict, wildlife poaching, illicit trade of species and their products and unregulated tourism. Until recently there had been no assessment of how well these protected areas were managed or whether they have achieved the goals and objectives set at their establishment.

The evaluation of the management effectiveness of protected areas is one critical tool to ensure protected areas are managed for biodiversity conservation, 

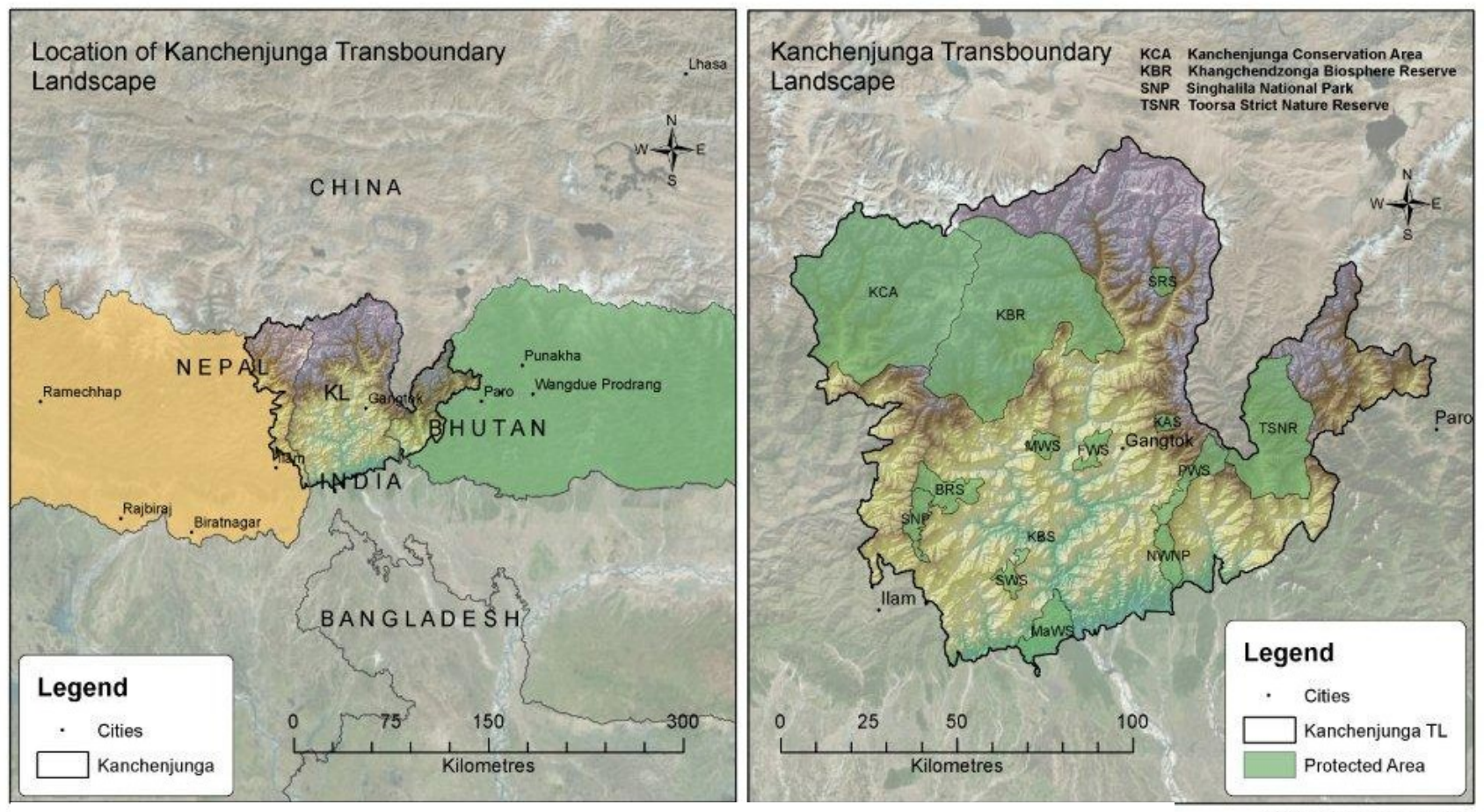

Boundaries are for guidance only and do not imply any opinion concerning legal status of any country or territory or the delineation of its boundaries

Map prepared by ICIMOD, 2013

Figure 1. Kanchenjunga Landscape showing protected areas and corridors

maintenance of vital ecosystem services, and provision of socio-economic benefits (BIP, 2011). Although the protected areas in $\mathrm{KL}$ are separated, the transboundary movement of bio cultural resources and sharing of environmental services has kept the landscape intact and alive. The landscape approach, and assessment of the effectiveness of management across the landscape, provides opportunities to learn from best practices to address conservation, ecological integrity and sustainable use of biological resources issues at a broader level defined by ecosystems rather than by political boundaries. Well managed protected areas harbouring participatory and equitable governance mechanisms yield significant benefits far beyond their boundaries, which can be translated into cumulative advantages across a national economy and contribute to poverty reduction and sustainable development including achievement of the Millennium Development Goals (Leverington et al, 2010). Considering these issues in particular, the assessment reported here intended to (i) assess the management effectiveness, (ii) assess governance status and its effectiveness, and (iii) identify threats, strengths, and weakness of current management and governance of the protected areas of the transboundary KL.

\section{STUDY AREA}

KL is part of Hindukush Himalayan region (Chettri et al., 2008) shared by Nepal, Bhutan and India and is a part of the Himalayan Biodiversity Hotspot (Mittermeier et al.,
2005; WWF-US, 2005). The landscape has 14 protected areas covering 6,037.96 $\mathrm{km}^{2}$ representing 40.9 per cent of the total area (Table 1). The landscape provides habitat for more than 100 mammal species, 550 birds and 600 butterflies (Chettri et al., 2008). Some of them are globally threatened species (Rana, 2008). Two-thirds of the protected areas in KL are IUCN category IV (Habitat/ Species Management area) (Sharma, 2010). Other protected areas fall under category Ia (Strict Nature Reserve), II (National Park) and VI (Protected Area with Sustainable use of Natural resources). The management responsibility for most of the protected areas in the landscape rests with the government although a few areas are co-managed. The landscape supports over 1.5 million people (Sharma, 2008). Agriculture and animal rearing are the dominant occupation, and there is a high dependency on biological resources for subsistence livelihoods.

For this study, four protected areas in India, Nepal and Bhutan were selected:

1. Toorsa Strict Nature Reserve, Bhutan (IUCN category Ia)

2. Singhalila National Park, Darjeeling, India (IUCN category II)

3. Khangchendzonga Biosphere Reserve, Sikkim, India (IUCN category V and UNESCO Biosphere Reserve)

4. Kanchenjunga Conservation Area, Nepal (IUCN category VI) 
Table 1: Protected areas of the Kanchejunga Landscape

\begin{tabular}{|c|c|c|c|}
\hline Country & Name of the protected area & IUCN category & Area km² \\
\hline 1. Nepal & Kangchenjunga Conservation Area & VI & 2,035 \\
\hline 2. India (Sikkim) & Khangchendzonga Biosphere Reserve & II & 2,620 \\
\hline 3. India (Sikkim) & Barsey Rhododendron Sanctuary & IV & 104 \\
\hline 4. India (Sikkim) & Fambong Lho Wildlife Sanctuary & IV & 51.76 \\
\hline 5. India (Sikkim) & Kyongnosla Alpine Sanctuary & IV & 31 \\
\hline 6. India (Sikkim) & Maenam Wildlife Sanctuary & IV & 35.34 \\
\hline 7. India (Sikkim) & Singhba Rhododendron Sanctuary & IV & 43 \\
\hline 8. India (Sikkim) & Pangolakha Wildlife Sanctuary & IV & 128 \\
\hline 9. India (Sikkim) & Kitam Bird Sanctuary & IV & 6 \\
\hline 10. India (WBengal) & Singhalila National Park & II & 79 \\
\hline 11. India (WBengal) & Senchal Wildlife Sanctuary & IV & 39 \\
\hline 12. India (WBengal) & Mahananda Wildlife Sanctuary & IV & 127 \\
\hline 13. India (WBengal) & Neora Valley National Park & II & 88 \\
\hline 14. Bhutan & Toorsa Strict Nature Reserve & la & 651 \\
\hline Total & & & $6,037.96$ \\
\hline
\end{tabular}

Source: Adapted from Chettri et al. (2008) and GOS (2007)

These protected areas represent the majority, 89 per cent (over $5,385 \mathrm{~km}^{2}$ ), of the protected area system in KL. Each has a different management regime and unique biodiversity resources. The management responsibility of Toorsa Strict Nature Reserve and Singhalila National Park rest with the government, while Khangchendzonga Biosphere Reserve is managed by the government in collaboration with local communities. The Kanchenjunga Conservation area in Nepal is managed by a local NGO in collaboration with the local communities.

\section{METHODS}

The assessment, which focussed on governance and livelihood issues, was made up of six separate activities:

\section{Literature review}

The first step in the assessment was a thorough review of available literature including management plans, national and international journal articles, research papers, theses, and project proposals to assess major aspects of management and governance of protected areas.

\section{Site level tracking tool}

The second step was the application of a simple site level management effectiveness tracking tool (METT) in the protected areas. This tool was developed by WWF and World Bank and has been applied since 2003 (Stolton et al., 2007); adaptations of the tool have been used in India in 2006 and 2011 to assess management effectiveness of tiger reserve (MoEF, 2011), and Nepali (2005) followed a similar approach for evaluating the protected areas of Nepal. The METT follows the structure of the World Commission on Protected Areas (WCPA) management effectiveness framework (Hockings et al., 2006); and considers the six elements of the management cycle (context, planning, inputs, process, outputs and outcomes) (Stolton et.al, 2007). In this study, the tool was adapted for use in the KL. A set of 37 questions considering each of these elements was developed and administered through a questionnaire survey (Annex I). A four-point scale: o (no or negligible progress), 1 (slight progress), 2 (good) and 3 (very good) was assigned to the elements. The METT was completed by the protected area managers and other stakeholders (e.g. residents, farmers/cattle herders, EDC/FPC officials, NGO officials, protected area field staff, and local body representatives such as Panchayat or Gewak leaders) during the field visits and discussions (see below). The scores were then tabulated by the authors along with the participants.

\section{Governance survey}

In addition to the adapted METT, a governance survey of 27 questions was developed following protected area governance principles and United Nations principles of governance (Annex II). The survey was conducted with a mixed group of stakeholders including park staff, local people, herders, representatives of community-based organisations, NGOs and youth clubs. Representatives 


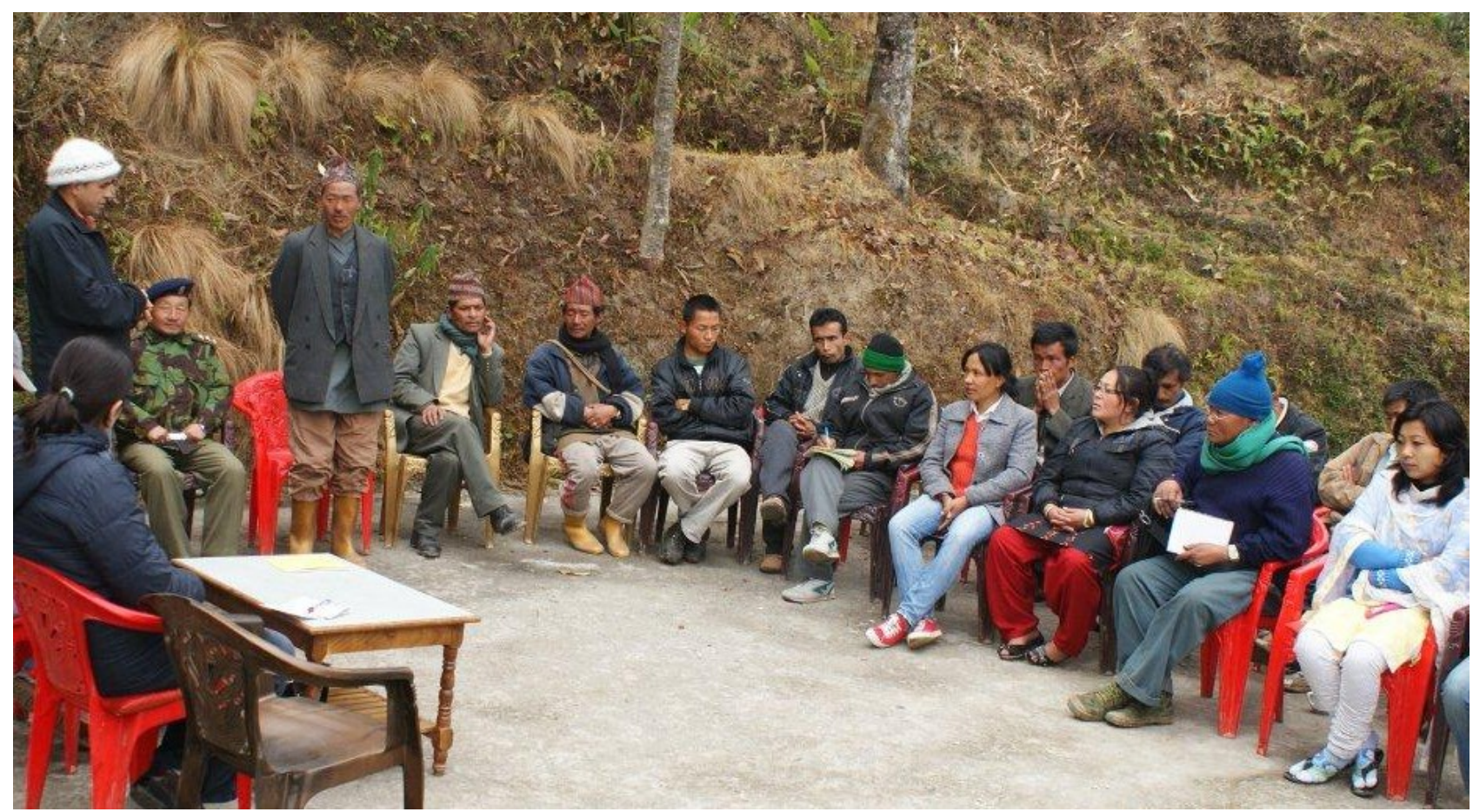

Focus group discussion with local communities, park rangers and key informants () Durga P. Sharma

from local government body such as Panchayat or Gewak leaders (leaders from local level bodies) were also surveyed. Altogether 100 individuals from different locations of KL took part in the survey.

\section{Reconnaissance survey}

The fourth step of the assessment was to visits the four protected areas to gather initial information on management resources, the administration system and other values that could not be ascertained from the literature review. During these visits the METT was completed, focus group discussion held and key informants survey completed.

\section{Key informants survey}

During the reconnaissance survey, key informants were chosen for semi-structured and one-on-one interview. Besides management and governance issues, the range of topics focused on strengths, challenges and threats in the protected areas such as community involvement in decision-making, benefit sharing, perception of local people towards protected areas and behaviour of park staff towards the local people. The key informants included local community leaders (men and women), shop keepers, researchers working for community based organisations and park authorities.

\section{Focus group discussion}

Focus group discussions were held for each of the selected protected areas. Altogether 12 themes for management effectiveness (context, planning, inputs, process, outputs and outcomes) and governance (do-noharm, accountability, legitimacy and voice, equity, direction and performance) were discussed along with strengths, challenges and threats.

For the Kanchenjunga Conservation Area (KCA) in Nepal, a meeting was held in March 2010 under the chairmanship of the warden of the KCA. 10 government officials including past and current employees of the KCA took part in the discussion. Similarly for the Toorsa Strict Nature Reserve, the discussion was held in Haa village in April 2010 under the chairmanship of the Gewak. Two of the 12 participants were women and the discussion was facilitated by the local forest officer and Nature Conservation Division official. Four discussions were held in Khangchendzonga Biosphere Reserve in Sikkim in June 2010, with 56 targeted participants including panchayat leaders, NGO officials, reserve staff, local residents and the Khangchendzonga conservation committee staff. Finally, discussions were conducted in late June with the local villagers, local NGO staff, farmers/cattle herders and the conservation committee for the Singhalila National Park of Darjeeling, India.

\section{RESULTS: EVALUATION OF MANAGEMENT EFFECTIVENESS}

An overall rating (given as a percentage of the total score) was given to each protected area based on set evaluation parameters focussed primarily on protected area governance, community relations and livelihood issues (Table 2). 
Table 2: Evaluation of Protected Areas of Kangchenjunga Landscape for Management Effectiveness

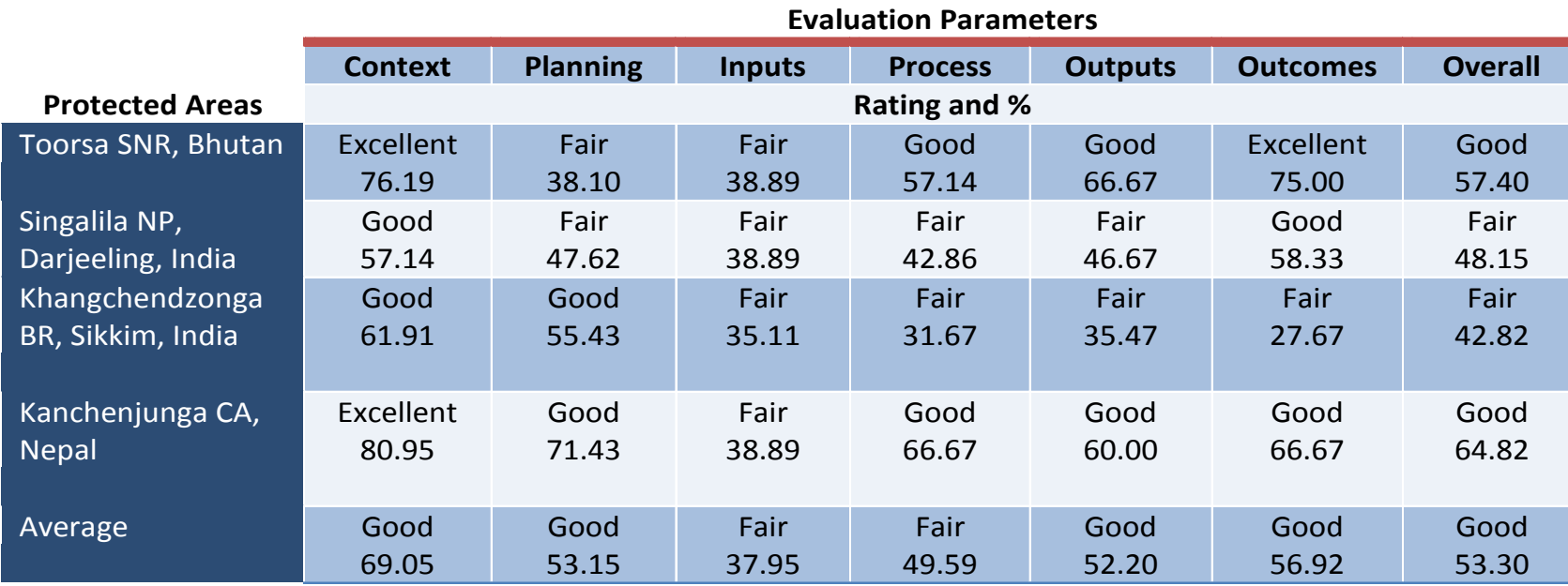

Rating criteria: Excellent: 75-100\%, Good: 50-74.9\%, Fair: 25-49.9\%, and Poor: $<25 \%$

The adapted METT assessment resulted in Toorsa Strict Nature Reserve scoring 57.40 per cent, which can be regarded as good (management above 50 per cent was considered good). The rating was validated during the focus group discussion where local people showed positive attitudes towards the park and commitment to participating in conservation and management. Implementation of Integrated Conservation and Development Programmes (ICDPs) in which people's concerns are taken into consideration shows the government is committed to the conservation of the reserve's resources and livelihoods of people.

KCA Nepal, which is fully managed through participatory conservation approaches by local people, scored 64.82 per cent. From the questionnaire survey of protected area staff, it was found that local values (including ecological, cultural and spiritual) have been considered carefully in management. Local people expressed that their economic well being has improved since the establishment of conservation area.

Singhalila National Park of India, in which the government holds authority, responsibility and accountability for management, received a 'fair' rating of 48.15 per cent. Management in this case was dependent on policy and governance structures at state and national level. The informants reported that people's participation was inadequate, especially in the preparation of management plan and decisions related to providing access to resources in the park or its buffer zone. The local people further expressed that they are not consulted for on-going planning and management decisions.

The results of the assessment in the Khangchendzonga Biosphere Reserve found staff were committed to protecting the reserve's important ecosystems. Local NGOs play a crucial role in promoting responsible tourism as well as bridging the gap in communication between local people and park authorities. However, the conventional management regime in which local people are excluded from management processes resulted in the management effectiveness score to be 42.82 per cent. The transhumance system ${ }^{\mathbf{1}}$ of animal rearing, which is an important part of landscape management, existed in the area for centuries but has been banned in the reserve and herders have not been compensated or provided with new income sources. This has created negative attitudes among local people, which were expressed during discussions and the informants' survey. People reported that the wildlife populations have been increasing, resulting in an increase in human-wildlife conflict including retaliatory killings. Furthermore, a comprehensive approach to settle such disputes has not been put in place.

The overall assessment shows that inputs in all the protected areas were weak with an inadequate number of staff, equipment and infrastructure, and poor financial provisions. The management system of the protected areas in India shows room for improvement, whilst the management systems in the protected areas of Bhutan and Nepal were in a satisfactory condition.

\section{KEY MANAGEMENT ISSUES}

Most of the protected area officials reported a lack of funds to meet the increasing responsibilities related to assessing and managing the protected areas and purchasing equipment. With increased eco-tourism, regular patrolling, vigilance and law enforcement are all important. For this the required trained manpower is not available in almost all the protected areas. All these 
protected areas are in remote areas, and the assessment found office infrastructure was insufficient and the living conditions of workers inadequate. There was little motivation and staff expressed their frustration at conditions. The findings of this study was similar to those reported by Nepali et al. (2005) who found limited staff and office facilities were one of the limitations for effective management in Nepalese protected areas. Surveyed staffs also reported limited training opportunities which have made them less aware of changing realities of protected area management, especially in the areas of monitoring wildlife populations, changes in forest compositions and team building.

Except for KCA in Nepal and Toorsa Strict Nature Reserve in Bhutan, local participation during annual planning was limited and management plans were prepared without their consultation. Some locals in Singalila National Park reported they are even not aware of the park. Although NGOs play an important role in raising conservation awareness and in community development around the protected areas, it was found that there is limited coordination between the park administration and NGOs.

Serious human-wildlife conflict issues were recorded in Sikkim, Darjeeling (GOS, 2008) where locals complained about their limited access to forest resources and the depredation of domestic animals and crops by wildlife for which they receive little or no compensation. By contract, the livestock insurance plan in KCA Nepal is an innovative scheme in which local people have developed a finance mechanism through which they receive compensation for the depredation of livestock by wildlife without having to wait for the government. The Royal Government of Bhutan is also piloting a livestock insurance policy programme in Toorsa and its biological corridor to reduce human-wildlife conflicts by formulating a policy of compensation.

\section{EVALUATION OF GOVERNANCE SYSTEM}

The analysis of the governance survey shows that governance parameters in India scored below 50 per cent which reflects the predominance of the conventional approach to making protected area management decisions. In the Khangchendzonga Biosphere Reserve, which scored 41.98 per cent, communities have limited involvement in governance. People are excluded from management and have limited access to resources from the reserve or its buffer zone. Similarly, in Singhalila National Park, which scored 32.44 per cent (Table 3), people's participation in park management is almost negligible, especially in the preparation of the management plan and decisions related to providing access to park resources.

With involvement of local people, conservation goals in India could be effectively achieved while providing maximum benefits from biodiversity conservation to the local communities at the same time. However legal frameworks make this difficult. The protected area authorities expressed their mandate to ensure effective implementation of the Wildlife Protection Act which prohibits settlements inside national park as well as access to resources within parks. The local communities in Sikkim and Darjeeling expressed their willingness to get involved in park management. However, many people are too scared to speak with park officials and have no avenue or voice to report wrong-doings or introduce innovative activities. This can be validated by the expression of one woman who said, "I feel that they are dealing with wilderness and have guns with whom we feel scared even to greet". The governance structures of these Indian protected areas thus have ample room for improvement leading towards more participatory management. As local people expressed a willingness to participate in protected area management, their opinions should be considered in major decisions. A focus should also be placed on sharing benefits with local communities.

The KCA Nepal scored 67.59 per cent. Issues of equity and performance have been adequately addressed in its management approach in which the government acts as a facilitator for local communities to responsibly manage the protected area (DNPWC, 2000). Encouraging results from community-based conservation and development initiatives in KCA have increased local people's sense of ownership towards the conservation area. Local people are satisfied with its management and mechanisms for the distribution of benefits seem to be satisfactory. However, the accomplishments should be monitored and evaluated regularly in order to continue to manage the area sustainably.

Similarly, Toorsa Strict Nature Reserve scored 58.02 per cent showing a satisfactory governance structure. Local people in the reserve are confident about their continuous access to resources and are gradually realizing their roles in the management of reserve and taking decisions related to management, boundary delineation, choice of supporting activities in ICDP and periodic evaluations. However, it has taken time for protected area officials to understand their accountability towards the communities. 
Table 3: Evaluation of Protected Areas of Kangchenjunga Landscape for Governance

\begin{tabular}{|c|c|c|c|c|c|c|c|}
\hline & $\begin{array}{l}\text { Do no } \\
\text { harm }\end{array}$ & $\begin{array}{l}\text { Legitimacy } \\
\text { and voice }\end{array}$ & Equity & Direction & $\begin{array}{l}\text { Perform- } \\
\text { ance }\end{array}$ & $\begin{array}{l}\text { Account- } \\
\text { ability }\end{array}$ & $\begin{array}{l}\text { Overall } \\
\text { Rating }\end{array}$ \\
\hline Protected Areas & \multicolumn{7}{|c|}{ Rating and \% } \\
\hline Toorsa SNR, Bhutan & $\begin{array}{l}\text { Good } \\
66.67\end{array}$ & $\begin{array}{l}\text { Good } \\
60.00\end{array}$ & $\begin{array}{l}\text { Good } \\
73.33\end{array}$ & $\begin{array}{l}\text { Good } \\
66.67\end{array}$ & $\begin{array}{l}\text { Fair } \\
33.33\end{array}$ & $\begin{array}{l}\text { Fair } \\
33.33\end{array}$ & $\begin{array}{l}\text { Good } \\
58.02\end{array}$ \\
\hline $\begin{array}{l}\text { Singalila NP, } \\
\text { Darjeeling, India }\end{array}$ & $\begin{array}{l}\text { Fair } \\
46.67\end{array}$ & $\begin{array}{l}\text { Fair } \\
33.33\end{array}$ & $\begin{array}{l}\text { Fair } \\
46.67\end{array}$ & $\begin{array}{l}\text { Fair } \\
46.67\end{array}$ & $\begin{array}{l}\text { Fair } \\
33.33\end{array}$ & $\begin{array}{c}\text { Fair } \\
44.44\end{array}$ & $\begin{array}{l}\text { Fair } \\
41.98\end{array}$ \\
\hline $\begin{array}{l}\text { Khangchendzonga } \\
\text { BR, Sikkim, India }\end{array}$ & $\begin{array}{c}\text { Fair } \\
26.53\end{array}$ & $\begin{array}{l}\text { Poor } \\
24.40\end{array}$ & $\begin{array}{l}\text { Fair } \\
46.67\end{array}$ & $\begin{array}{l}\text { Fair } \\
42.13\end{array}$ & $\begin{array}{l}\text { Poor } \\
22.17\end{array}$ & $\begin{array}{c}\text { Fair } \\
29.56\end{array}$ & $\begin{array}{l}\text { Fair } \\
32.44\end{array}$ \\
\hline $\begin{array}{l}\text { Kanchenjunga CA, } \\
\text { Nepal }\end{array}$ & $\begin{array}{c}\text { Excellent } \\
86.67\end{array}$ & $\begin{array}{l}\text { Good } \\
73.33\end{array}$ & $\begin{array}{l}\text { Good } \\
66.67\end{array}$ & $\begin{array}{l}\text { Good } \\
73.33\end{array}$ & $\begin{array}{l}\text { Good } \\
50.00\end{array}$ & $\begin{array}{l}\text { Good } \\
55.56\end{array}$ & $\begin{array}{l}\text { Good } \\
67.59\end{array}$ \\
\hline Average & $\begin{array}{l}\text { Good } \\
56.64\end{array}$ & $\begin{array}{c}\text { Fair } \\
47.78\end{array}$ & $\begin{array}{l}\text { Good } \\
58.34\end{array}$ & $\begin{array}{l}\text { Good } \\
57.20\end{array}$ & $\begin{array}{l}\text { Fair } \\
34.71\end{array}$ & $\begin{array}{c}\text { Fair } \\
40.72\end{array}$ & $\begin{array}{l}\text { Good } \\
50.01\end{array}$ \\
\hline
\end{tabular}

Rating criteria: Excellent: 75-100\%, Good: 50-74.9\%, Fair: 25-49.9\%, and Poor: <25\%

Table 4: Threats to protected areas in the Kangchenjunga Landscape

\begin{tabular}{|c|c|c|c|c|}
\hline Identified threats & KCA, Nepal & $\begin{array}{l}\text { Sikkim PAs, } \\
\text { India }\end{array}$ & $\begin{array}{l}\text { Darjeeling } \\
\text { PAs, India }\end{array}$ & $\begin{array}{c}\text { Toorsa SNR, } \\
\text { Bhutan }\end{array}$ \\
\hline Livestock grazing & $\mathbf{v}$ & $\sqrt{ }$ & $\sqrt{ }$ & $\mathbf{v}$ \\
\hline Poaching of wildlife & $\sqrt{ }$ & $\sqrt{ }$ & $\sqrt{ }$ & \\
\hline Illegal harvest of fuelwood and timber & $\sqrt{ }$ & & $\sqrt{ }$ & \\
\hline Illegal harvest of NTFPs & $\sqrt{ }$ & $\boldsymbol{v}$ & $\sqrt{ }$ & $\mathbf{v}$ \\
\hline $\begin{array}{l}\text { Diversion of rivers and streams, dam } \\
\text { construction }\end{array}$ & & $\sqrt{ }$ & $\sqrt{ }$ & \\
\hline Settlement and forest encroachment & $\sqrt{ }$ & & $\sqrt{ }$ & \\
\hline Tourism & & $\sqrt{ }$ & $\sqrt{ }$ & \\
\hline Crop/livestock depredation by wildlife & $\sqrt{ }$ & $\sqrt{ }$ & $\sqrt{ }$ & $\sqrt{ }$ \\
\hline Forest fires & $\sqrt{ }$ & $\sqrt{ }$ & $\sqrt{ }$ & $\sqrt{ }$ \\
\hline Weak institutional capacity & $\sqrt{ }$ & $\mathbf{v}$ & $\sqrt{ }$ & $\mathbf{v}$ \\
\hline
\end{tabular}

\section{THREATS}

Threats were identified based on discussions with different focus groups; the most prominent threats were weak institutional capacity, depredation by wildlife, livestock grazing and illegal harvesting of resources (see table 4).

The results of the study show that many of the threats to protected areas are similar to those observed at the time of their designation. However, the results also showed that the severity of threat is not uniform across all the studied protected areas. For example in KCA, Nepal, hunting was a major problem before the conservation area was declared and handed over to the communities. This problem was greatly reduced along with the meaningful engagement of communities (WWF-Nepal, 2007). "With the communal harmony and unity amongst local people, the conservation effort has received huge boost in the area" reported one park ranger. This clearly shows that when confidence and responsibility are placed in local communities, they are more compelled to protect biological resources and enhance ecosystem function. However overall protection mechanisms also need to be strengthened in KL to deter illegal hunting from the protected areas.

Illegal harvest of non-timber forest products, fuelwood and timber are prevalent in all the protected areas to varying degree. The issue remains unresolved due to a lack of policy intervention. There has been some attempt in Nepal at the policy level to promote the sustainable harvest of forest resources from forests (Sharma et al., 2004), but implementation has been far from satisfactory. 


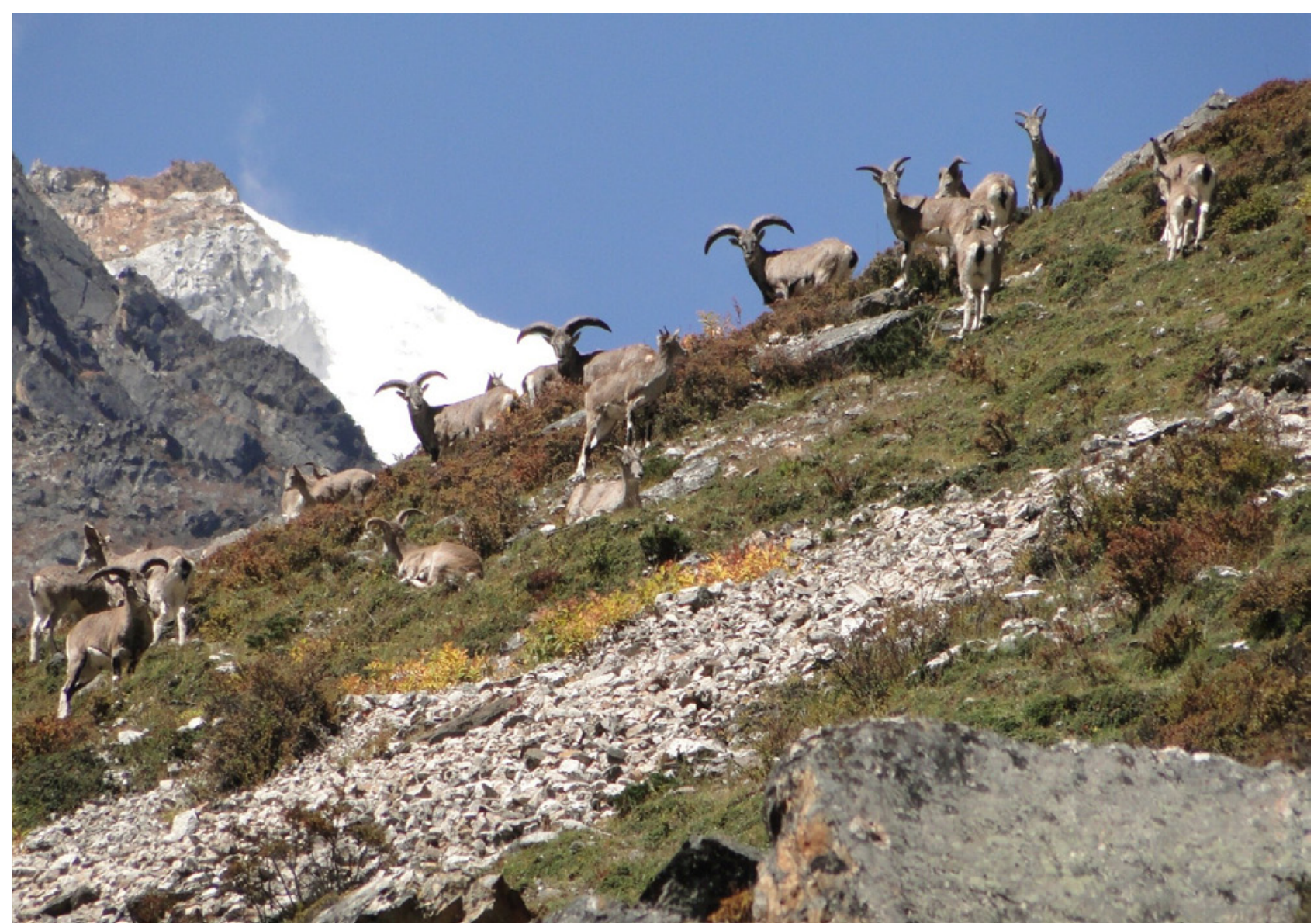

Blue sheep main prey species of snow leopard in KCA 2010 (C) KamalThapa

\section{STRENGTHS AND WEAKNESS OF PROTECTED AREA MANAGEMENT}

The strength of each protected area varied based on available funds, human resources and participation of community in park management. The strengths and challenges across all protected areas are summarised as follows:

- During the discussion and interview, the key informants and park authority representatives reported that the legal status and ownership of the protected area in each country is clear and defined. Protection in each country is substantially high and effective at protecting the ecosystems and species within their borders despite land use pressure along the borders. Similar results were reported by Bruner et al (2001) from the evaluation of 93 parks in 22 tropical countries.

- All the four parks have management plans and governments have set aside annual budgets with allocation for permanent staffs.

- Conservation Area User Committees (KCA Nepal) are active in conservation activities which have helped reduce the over harvesting of resources and wildlife poaching. They also provide economic benefits to communities through projects. In India Ecodevelopment Committees are institutionalised, but their impacts on the conservation and development are yet to be realised

- Efforts by NGOs have helped bridge the gap between protected area officials and local communities, and foster sustainable development in the KL.

- However, management planning processes seldom include local communities and management plans do not have adequate provisions to deal with local resource use and programmes for better livelihoods. Except for KCA in Nepal management structures are not designed to promote participatory modes of working.

- There is a general lack of field staff, inadequate provision of equipment and physical infrastructures, and limited capacity building training.

- Limited budgets mean that most available resources are spent on patrolling and supervisory activities and not on research, monitoring and evaluation.

- Eco-development committees in India are not fully functional and self-governing organizations and have limited legal rights.

- Human-wildlife conflicts in and around protected areas have increased and more comprehensive approaches to address this issue should be introduced, including schemes for community-based compensation. 


\section{STRENGTHS AND CHALLENGES OF PARK GOVERNANCE}

- People are gradually realizing the value of protected areas and their role in management and are willing to engage in major decision making.

- Community based conservation and development initiative in KCA, Nepal have shown that local people can be trusted in protected areas management. In KCA, people's feeling of ownership of the protected areas is high, a situation which can be seen as an example for the rest of the KL.

- The 'preservation' mind set of authorities is gradually changing towards one of greater "inclusiveness".

- However, in some cases limited coordination and consultation between protected areas officials and local people is triggering park people conflicts.

- Governance structures that include local people are lacking, especially in Indian protected areas.

- Eco-development committees (EDCs) and Forest Protection Committees (FPCs) which are formed to help the park administration for the protection of forests in India are not considered partners in protected areas governance and management, but rather considered as separate entities.

- There is a lack of clear legally binding mechanisms of sharing the cost and benefits between EDCs, FPCs and protected areas.

\section{DISCUSSION}

The METT has been applied in more than 85 countries with some modifications in Asian countries (Leverington et al., 2010). The tool proved useful in assessing the management effectiveness of protected areas that are part of large, transboundary landscape with different national jurisdictions and legal frameworks. With the overall aim of improving protected area management in the KL, the application of the METT gave a clear view of the management status, threats, strengths and weakness of protected areas within the landscape. The tool was supported by the governance survey, field visits, focus group discussions and key informant's survey which gave a clear picture of management and governance structures.

Almost all the respondents reported that the ecosystem has been maintained or restored due to the presence of protected areas. This fact was obvious when viewing the other land uses along the protected area borders during the field trip. Where in place, participatory approaches to park management have increased support for the protected area but the ecological impacts of such approaches, which include anthropogenic activities, have not been scientifically assessed or validated due to the lack of research and monitoring in the area. Sustainable harvesting and the removal of higher and lower plants and animals will have impacts and is a major issue to address in the future. Similarly, traditional land use practices such as pastoralism as a tool to managing the ecosystem have been abandoned; studies are required on the augmentation or reduction of biological resources as a result.

Strengths and challenges of management and governance revealed by the assessment provide future courses of action to be taken to improve management across the landscape. For example, weak institutional capacity was identified as a major challenge in all protected areas reflected inadequate staffing, equipment and infrastructure. This also reflects limited training opportunities for field based park staff, EDC and NGO officials, and other community workers. Inadequate funding and inadequate access to research-based information for protected area management were also noted. Other barriers inhibiting effective management include government policies and legal frameworks evolved from conventional models that still undermines the full participation of local communities. The process of integrating relevant actors in protected area management needs to be promoted.

It is still too early to say if the ICDP approach of management in Nepalese and Bhutanese protected areas has maintained the balance between conservation and development. Nevertheless, the findings of the study provide base-line information for future evaluation and to raise awareness among protected area and other stakeholders on the methodology applied in the study.

In addition the study outlines strengths and weakness of all protected areas, which will help the managers to improve management and accountability and to influence policy. The results suggest that protected area authorities should also be prepared to listen to their critics, be willing to adopt new ways of managing and governing protected areas, be motivated in understanding anthropological dynamics of the local community and be respectful to their traditional ways of conserving biological resources. There are progressive methods being applied within the landscape, for example biological corridor policies of Bhutan (Wangchuk, 2007) and Nepal. If successful methodologies are adapted and monitored, protected area management can be made more effective and governance can be greatly improved. 
Finally, the study showed a clear need to increase support for protected areas to improve effectiveness against all threats. The findings suggest that protected areas should remain a central component of conservation strategies to maintain biodiversity and ecosystem functioning. Bringing local communities into protected area management and helping protected areas perform better will provide a significant contribution to long-term biodiversity conservation in the transboundary landscapes in the Himalayas.

\section{NOTES}

1 Transhumance, a developed form of pastoralism, which describes the seasonal movement of people with their livestock between fixed summer and winter pastures, or the cyclic movement of people and livestock to maintain a balance between demand and supply of pasture.

\section{ANNEX I: MANAGEMENT EFFECTIVENESS QUESTIONNAIRE}

\section{Context}

1.1: Legal status: Notification done? Protected area (PA) rules and regulations available?

1.2: Are there enough staff and equipment to enforce PA law?

1.3: Are there boundary disputes?

1.4: Are the demarcation posts/marks readily identifiable and known to people?

1.5: Level of acceptance or resentment towards the PA? (include in the answer what they had to forgo for the PA: hunting, fishing, collection of NTFP, firewood, timber, stones/ boulders, etc.)

1.6: Were people displaced during the establishment of the PA? (Include in the answer any details provided)

1.7: Assess the current human footprint in the PA due to infrastructure and activities that include roads/irrigation canals, illegal harvest of resources, land encroachment, modification of forests, mining and pollution (entering or generated)?

1.8: If 1.7 is true, was there any provision of EIA for activities that have direct impacts on biodiversity. If EIA was undertaken, was the mitigation planned implemented?

[Only additional information, not for score purpose]

\section{Planning}

1.9: Is there a management plan and is it being implemented?

1.10: Does the plan clearly identify key threats?

1.11: Is there a plan to abate these threats?

1.12: What are the key species protected? Is the PA of the right size and shape to protect these species?

1.13: Does the PA represent a unique ecosystem and/or protect endangered species?

1.14: Do people understand the core values of the PA and do they believe in them?

1.15: Is there a rolling operational work plan and is it being implemented?

Inputs

1.16: Are staff and community leaders trained/oriented on a regular basis?

1.17: Are there enough staff members to manage the PA?

1.18: Is the natural resource actively managed?

1.19: Is equipment sufficient?
1.20: Is the current budget adequate to implement programmes?

1.21: If there is a funding shortfall, is there a plan to ensure the growth of income matches or exceeds the growth of expected costs of PA management?

Process

1.22: Is there a planned outreach programme linked to objectives and needs?

1.23: Is the role of indigenous people and local communities/ marginalized people in the PA management synergetic, constructive?

1.24: Are there sufficient programmes to address the welfare needs of the local communities?

1.25: How is tourism in the PA perceived?

1.26: Do tour operators' activities contribute to PA management?

1.27: If fees are applied for entrance or other services, does a share return to the benefit of the communities and/or to the PA?

1.28: Are management activities actively monitored against performance?

Outputs

1.29: Do local people and/or indigenous/marginalized people actively support PA?

1.30: Is the PA seen as a source of providing economic benefits, employment or other opportunities for local people's wellbeing?

1.31: Is the PA seen as the provider of environmental services?

1.32: Are visitor facilities adequate for the demand?

1.33: Based on your interactions with visitors and tour operators, how do you rate visitor satisfaction?

Outcome

1.34: Is it the belief that the condition of important PA values (especially biodiversity and cultural values) is enhanced because of the presence of the PA?

1.35: How do people perceive the role of PA authorities?

1.36: If not happy, where they see the need to improve?

1.37: What is the best impact the PA has made in their community, in the neighborhood, and/or in livelihood in general?

\section{ANNEX II: GOVERNANCE QUESTIONNAIRE}

Do no harm

1.1: What was the role of local communities and indigenous/ marginalized/influential people when the PA was notified?

1.2: Were people re-settled? If yes, how they have taken this move?

1.3: Is there anyway local communities feel humiliated due to PA?

1.4: What good happened to local people after PA was established?

1.5: Does PA legislation respect customary laws, age-old practices?

Legitimacy and Voice

1.6: Who makes major decision in PA management, especially when it comes to using PA resources?

1.7: Are people allowed to use the PA resources?

1.8: Is there discrimination of ethnic groups and social class, gender?

1.9: Are the PA management objectives, strategies, activities developed through collective agreements between different stakeholders? 
1.10: Is there preference for jobs for local people? Is the procedure transparent?

\section{Equity}

1.11: Do all men and women have fair opportunity to improve or maintain their well-being within and outside the PA?

1.12: Are people allowed to live within the PA?

1.13: Is the law enforcement just?

1.14: Is there a fair and equitable system(s) of distribution of costs and benefits of conservation?

1.15: Is there a fair management practice of PA staff?

Direction

1.16: How sympathetic is PA management towards local people's concerns and innovative ideas?

1.17: Does the PA provide effective leadership by fostering and maintaining an inspiring and consistent vision for the PA in long-term management?

1.18: Does PA management make efforts to mobilize support for the vision and garner funds?

1.19: Are PA objectives clear to the stakeholders?

1.20: Provide best examples of partnership and/or taking initiatives.

Performance

1.21: Is the capacity of staff ensured to carry out roles and assume responsibilities?

1.22: How is the PA management structure rated? Robust, resilient, etc?

1.23: How does the PA management deals with the complaints and criticism?

1.24: Are people involved in the monitoring and evaluation as part of an adaptive management strategy?

Accountability

1.25: Is the PA management accountable to the public at large?

1.26: How are the media entertained for any investigative reporting?

1.27: Are PA officials rewarded for their exceptional work benefitting communities or punished for any wrongdoing that especially affects communities.

\section{REFERENCES}

Bertzky, B., Corrigan, C., Kemsey, J. et al. (2012). Protected Planet Report 2012: Tracking progress towards global targets for protected areas: Key protected area facts for decision makers. Gland, Switzerland: IUCN and Cambridge, UK: UNEP WCMC

Bruner, A. G., Gullison, R. E., Rice, R. E. and G. A. B. da Fonseca. (2001). Effectiveness of Parks in Protecting Tropical Biodiversity, Science 291, 5 January 2001

Biodiversity Indicators Partnership (BIP). (2011). Guidance for national biodiversity indicator development and use. Cambridge, UK: UNEP WCMC

Boyle, M., Ervin, J. and C. M. Hogan. (2010). Biological corridor. In: Ed. C. J. Cleveland., Encyclopedia of Earth. First published in the Encyclopedia of Earth May 20, 2010; Revised September 20, 2010; Retrieved March 9, 2013 http://www.eoearth.org/article/Biological_corridor? topic $=58074 . \mathrm{com}$

Chettri, N., B. Shakya, R. Thapa, and E. Sharma. (2008). Status of a protected area system in the Hindu Kush-Himalayas: an analysis of PA coverage. International Journal of Biodiversity Science and Management 4: 164-178

DNPWC. (2000). Government Managed Conservation Area Management Regulations. Kathmandu, Nepal:
Department of National Parks and Wildlife Conservation (DNPWC)

Government of Sikkim (GOS). (2008). Management Plan of the Khangchendzonga National Park 2008-2018. Gangtok, India: Wildlife Circle, Forests, Environment and Wildlife Management Department

Hockings, M., Stolton, S., Leverington, F., Dudley, N., and J. Courrau. (2006). Evaluating Effectiveness: A Framework for Assessing Management Effectiveness of Protected Areas: Second edition. Gland, Switzerland: IUCN

Kothari, A. (1999). Towards participatory conservation in India: National scenario and lessons from the field. Pages: 117-149. In: Oli, K.P. (ed.), Collaborative Management of Protected Areas in the Asian Region. Kathmandu, Nepal: IUCN

Leverington, F., K. Costa, J. Courrau, H. Pavese, C. Nolte, M. Marr, L. Coad, N. D. Burgess, B. Bomhard, and M. Hockings. (2010). Management effectiveness evaluation in protected areas: a global study. Second edition. St. Lucia, Queensland, Australia: University of Queensland, IUCNWCPA, TNC, WWF

Mittermeier R. A., Gils P. R., Hoffman M., Pilgrim J., Brooks T., Mittermeier C.G., Lamoreaux J. and G. A. B. da Fonseca (eds.). (2005). Hotspots Revisited. Earth's biologically Richest and Most Endangered Terrestrial Ecoregions. USA: University of Chicago Press

MoEF, Government of India. (2011). Management Effectiveness Evaluation of 39 tiger reserves in India. New Delhi, India: Government of India. www.projecttiger.nic.in/whtsnew/meetr_tiger_2011.pdf

Nepali, S. C. (2005). Rapid Assessment and Prioritization of Protected Area Management in Nepal. Kathmandu, Nepal: WWF

Rana, L. N. (2008). Biodiversity status in the potential conservation corridors of the Kanchenjunga Landscape: a distribution model of flagship and indicator species. In Biodiversity conservation in the Kanchenjunga Landscape. Kathmandu, Nepal: ICIMOD

Sharma, U. R. (2010). Kangchenjunga landscape: opportunities for transboundary sharing of knowledge and skills. Biodiversity Conservation Efforts in Nepal Newsletter, special issue for the $15^{\text {th }}$. Kathmandu, Nepal: DNPWC

Sharma, U. R., Malla, K. J. and R. Uprety. (2004). Conservation and management efforts of medicinal and aromatic plants in Nepal. Banko Janakari 14(2): 3-11

Stolton, S., Hockings, M., Dudley, N., MacKinnon, K., Whitten, T. and F. Leverington. (2007). Reporting progress in Protected areas. A site level Management Effectiveness Tracking tool: second edition. Gland, Switzerland: World Bank/WWF Forest Alliance and WWF. http:// www.wdpa.org/ME/PDF/METT.pdf

Wangchuk, S. (2007). Maintaining ecological resilience by linking protected areas through biological corridors in Bhutan. Tropical Ecology 48(2): 176-187

WWF-Nepal. (2007).Understanding the changes in Livelihood assets with Locals: A case study for Kanchenjunga Conservation Area Project, Nepal. Sacred Himalayan Landscape in Nepal. Series No.3.

WWF-US, Asia Programme. (2005). Ecosystem Profile. Eastern Himalaya Region. Final report. Critical Ecosystem Partnership Fund. www.cepf.net/Documents/ final.ehimalayas.ep.pdf. Accessed on 22nd Feb 2013, Washington DC, USA: WWF-US 


\section{ABOUT THE AUTHORS}

Krishna Prasad Oli, Ph.D has a background in agriculture, animal science, geography and law and has worked extensively In the Hindukush Himalayan region and beyond promoting biodiversity conservation, ABS policy , participatory management of protected area with governments, NGO's and local communities. He has worked with ICIMOD for the last eight years as a professional in Transboundary landscape management. Currently he is engaged in promoting the implementation of ABS mechanism, CBD Nagoya protocol and CITES in the Himalayan countries.

Uday Raj Sharma, Ph.D is a wildlife biologist trained in USA. He has spent a large part of his career supporting the government of Nepal in setting up protected area systems and building on participatory protected area management. He is now retired from government civil service, after reaching the top post of secretary under the
Ministry of Forests and Soil Conservation. He has been a biodiversity management consultant at ICIMOD, served under several different portfolios including the Director General of the Department of National Parks and Wildlife and worked as a protected area management consultant with UNDP. He also served as regional vice chair of WCPA South Asia. Currently he is a freelance consultant.

Sunita Chaudhary, M.Sc holds a Master's in management of protected areas from the University of Klagenfurt, Austria and a Bachelor's in Forestry from Nepal. She is also a graduate of the University of Hawaii, United States. Since 2010, she has worked at ICIMOD as a research associate on ecosystem services and transboundary biodiversity conservation and management. She has worked in Europe, Southeast Asia and Hindu Kush Himalaya region of South Asia she has numerous publications to her credit.

\section{RESUMEN}

Se hizo una evaluación sobre la gobernanza y la eficacia de la gestión en cuatro áreas protegidas del paisaje del monte Kanchenjunga compartido por Bután, India y Nepal, empleando una herramienta sencilla de seguimiento a nivel de sitio. El estudio se reforzó tanto con discusiones de grupos focales, como con un estudio de participantes clave y visitas de campo. La evaluación de la gestión reveló que las áreas protegidas son sistemáticamente débiles en lo referente a insumos como cantidad de personal y equipo, provisión financiera e infraestructura. Los resultados sugieren la necesidad de mejoras en materia de gestión. La Reserva de la Biosfera de Khangchendzonga y el Parque Nacional Singhalila en la India obtuvieron un 41,98 y 32,44 por ciento, respectivamente. El Área de Conservación Kanchenjunga de Nepal y la Reserva Natural Estricta Toorsa de Bután obtuvieron una calificación un poco más alta: 67,59 y 58,02 por ciento, respectivamente. La escasa capacidad institucional, la depredación de la vida silvestre, el pastoreo de ganado y la tala ilegal de los recursos fueron señalados como amenazas. Entre los principales problemas destacan la limitada participación de la población local en la toma de decisiones y en la gestión de las áreas protegidas. Los resultados apoyan la recomendación de que se deben hacer esfuerzos para pasar de un enfoque proteccionista a un enfoque de conservación basado en la comunidad para la conservación y el uso sostenible de los recursos biológicos en el paisaje.

\section{RÉSUMÉ}

Une évaluation a été menée sur la gouvernance et l'efficacité de la gestion de quatre aires protégées du paysage de Kanchenjunga, qui se partage entre le Bhoutan, l'Inde et le Népal, grâce à l'utilisation d'un outil de suivi très simple à l'échelle locale. L'étude s'est ensuite appuyée sur des discussions thématiques de groupes, une enquête auprès des principaux répondants et des visites sur le terrain. L'évaluation de la gestion a ainsi révélé que les aires protégées manquent systématiquement de personnel, d'équipement, de réserves financières et d'infrastructures. Des améliorations de la gestion sont donc nécessaires : la réserve de biosphère de Khangchendzonga et le Parc national de Singhalila en Inde ont ainsi des taux respectifs de 41,98\% et 32,44\%. La zone de conservation de Kanchenjunga au Népal et la Réserve naturelle intégrale Toorsa au Bhoutan ont des taux légèrement supérieurs, de 67.59\% et 58.02\% respectivement. Les principales menaces sont la faiblesse des capacités institutionnelles, la dégradation par la faune sauvage, le pâturage du bétail et la récolte illégale de ressources. Par ailleurs, la participation limitée des populations locales dans la prise de décision et la gestion des aires protégées est un défi de taille à relever. L'étude préconise donc de faire des efforts et d'abandonner l'approche protectionniste pour adopter une approche basée sur les communautés qui favorise la conservation, afin de conserver et d'utiliser de manière durable les ressources biologiques du paysage. 